NBER WORKING PAPER SERIES

REFORM OF ILL-HEALTH RETIREMENT BENEFITS FOR POLICE IN ENGLAND AND WALES: THE ROLES OF NATIONAL POLICY AND LOCAL FINANCE

\author{
Rowena Crawford \\ Richard Disney \\ Working Paper 18479 \\ http://www.nber.org/papers/w18479 \\ NATIONAL BUREAU OF ECONOMIC RESEARCH \\ 1050 Massachusetts Avenue \\ Cambridge, MA 02138 \\ October 2012
}

This paper was prepared for the NBER Conference on 'Retirement benefits for state and local employees: Designing pension plans for the twenty-first century', held at Jackson Lake Lodge Wyoming in August 2012. We thank the organisers of the latter for the invitation to present this paper. We are grateful to seminar participants at the Institute for Fiscal Studies, and at this NBER conference for comments and particularly, in some cases, for detailed and helpful suggestions on an earlier draft. We thank the Chartered Institute of Public Finance and Accountancy (CIPFA) and the Home Office for making available some of the data used here. The views expressed here are those of the authors and do not necessarily reflect the views of either these bodies, nor of any organization or review team of which the authors have been part, nor of the National Bureau of Economic Research.

NBER working papers are circulated for discussion and comment purposes. They have not been peerreviewed or been subject to the review by the NBER Board of Directors that accompanies official NBER publications.

(C) 2012 by Rowena Crawford and Richard Disney. All rights reserved. Short sections of text, not to exceed two paragraphs, may be quoted without explicit permission provided that full credit, including (c) notice, is given to the source. 
Reform of Ill-health Retirement Benefits for Police in England and Wales: The roles of National Policy and Local Finance

Rowena Crawford and Richard Disney

NBER Working Paper No. 18479

October 2012

JEL No. H75,J26,J45

\begin{abstract}
$\underline{\text { ABSTRACT }}$
We examine the ill-health retirement of police officers in the forces of England and Wales between 2002-03 and 2009-10. Differences in ill-health retirement rates across forces are statistically related to area-specific stresses of policing and force-specific differences in human resources policies. Reforms to police pension plans - in particular a shift in the incidence of financing ill-health retirement from central government to local police authorities - occurred in the mid-2000s. We show these measures impacted on the level of ill-health retirement, especially on forces with above-average rates of retirement. We find that residual differences in post-2006 ill-health retirement rates across forces are related to their differential capacities to raise revenue from local property taxes.
\end{abstract}

Rowena Crawford

Institute for Fiscal Studies

7 Ridgmount Street London WC1E 7AE

rowena_c@ifs.org.uk

Richard Disney

Institute for Fiscal Studies

7 Ridgmount Street

London

WC1E 7AE

England

richard_d@ifs.org.uk 


\section{Reform of Ill-health Retirement Benefits for Police in England and Wales: The roles of national policy and local finance}

\section{Introduction}

This paper examines variations in early retirement on grounds of ill-health among police officers across police forces in England and Wales. Although the previous century saw a gradual transition towards centralised negotiation of pay, pensions and conditions of service among the police forces of the United Kingdom, local forces retain significant discretion over hiring and hiring standards, in deployment of officers and staff, and over retention polices towards police officers.

We investigate variations in ill-health retirement policies across police forces after controlling for selected characteristics of police officers and differences in the nature of policing across police areas. We show that there is significant residual variation in rates of ill-health retirement across forces after controlling for these factors. There are also differences across police forces in the reliance on central versus local funding of police activities. We illustrate the downward trend in ill-health retirement rates over time, in part driven by the policies of central government - including a partial shift in the burden of financing ill-health retirement from the national to local level. We explore whether there is a connection between the relative trends in ill-health retirement across police forces and in each force's capacity to raise funds for police activities from local property taxes. To do so, we use novel data that exploits variations in key variables across police forces and over time.

In the context of research in the United States on local pensions: this paper complements the discussion there as to the extent of variation in retirement policies in public pension plans at the municipal or local level relative to the state jurisdiction (see, for example, Friedberg, 2012). Given the United Kingdom's pension context, the national governments of England and Wales may be regarded as acting in a comparable role to the 'state' in the United States, with the national pension arrangements for public sector workers in the UK being analogous to the centralised public pension arrangements in some US states (such as Michigan). Despite this 
centralisation of the negotiation of pay and pensions, however, the bulk of policing in the United Kingdom is carried out at the county or municipal level as in the United States. ${ }^{1}$

The paper is structured as follows. Section 2 provides a brief institutional background on institutions, and on pension and retirement policies in the police service. In particular, it discusses reforms implemented in 2006 to reduce ill-health retirement rates both by targeting 'high ill health retirement rate' forces and by transferring part of the burden of financing ill health retirement onto local forces themselves. The impact of these measures on ill health retirement rates is investigated statistically in Section 3 of the paper. In Section 4 we consider further the implications of the partial devolution of the funding of ill-health retirement to local police authorities. We examine whether police authorities with higher local taxable capacity from local property taxes pursued different ill-health retirement strategies in the post-2006 period to those with lower capacity. To our knowledge this is the first study of its kind concerning the issues of ill-health retirement, local taxable capacity and pension policies among public sector workforces in the United Kingdom.

\section{Background}

\subsection{Institutions}

As in the United States, policing in England and Wales is largely carried out at the local level rather than at the national jurisdiction by territorial police forces. Forces are normally organised at the county level, albeit with some county forces merged into larger 'territorial areas' (e.g. 'Thames Valley') or 'joint forces' covering larger municipal areas such as Greater Manchester and, for most of London, the Metropolitan Police. In all there are 43 police forces in England and Wales; the nations which are the focus of our analysis. A typical police force in England and Wales covers a population of around 1 million people, although the joint forces typically cover larger populations and, in the case of the Metropolitan Police, over 10 million people. $^{2}$

\footnotetext{
${ }^{1}$ To pursue the analogy up to the Federal level in the United States: England, Wales, Scotland and Northern Ireland are separate legal jurisdictions, although much of what is described here applies to the police forces in all those nations. There is also the wider 'Federal' question of harmonisation of pension arrangements among members of the European Union, of which the United Kingdom is one, although these have so far been left to the discretion of individual members.

2 As is apparent a 'county' in England and Wales is typically a larger territorial jurisdiction in terms of population than a county in the United States.
} 
Although policing thereby has a decentralised territorial aspect in England and Wales, akin to the United States, there is a much greater degree of centralisation in policing policy in the former. All police officers, irrespective of rank, are appointed to the national 'Office of Constable' - a procedure dating back to the year 1066 (but more recently and mundanely enshrined in the Police Acts of 1964 and 1996) - by which an officer is sworn into the office by their local police force and thereby gains powers of search and arrest that are not available to the general public, including, under certain conditions, the power to arrest outside their own territorial area.

Police officers do not have an 'employment contract' with an individual police force, and thereby lack certain standard employment 'rights' such as the right to form a trade union and take industrial action, or to take part in political activities. Equally, except under certain very specific conditions, a police officer cannot be made redundant, and will continue in the 'office of constable' (irrespective of actual rank) until he or she cannot undertake the full variety of tasks both physical and mental - required by their office. For that reason, the age of 'normal' retirement for a police officer has traditionally been set at a relatively young age - either on attaining age 50 or after 30 years of service.

\subsection{Pay and pensions}

In contrast also to the United States, the determination of police remuneration in the UK has become increasingly centralised over time. At the turn of the twentieth century - when there were many more local police forces in the UK - pay was set locally but in 1918 two important changes occurred. First a 50\% central exchequer grant was introduced to supplement finance of police forces from local property taxes. Secondly, local police authorities were required to place their police forces on one of two standard pay scales. These were broadly consolidated into a single scale (albeit with additional allowances especially for officers within the (London) Metropolitan Police) as a result of the report of the Royal Commission on the Police of 1962. Police pay (and increases thereof) is now set by the Home Secretary - a senior minister in national government - albeit after the operation of a statutory negotiating framework for changes to pay and conditions. Attempts to reform police pay and conditions, most recently in the form of comprehensive proposals from the 'Independent Review of Police Officer and Staff 
Remuneration and Conditions' (Winsor, 2011, 2012), are also dealt with through this negotiating machinery. ${ }^{3}$

Pension provisions of the police are as follows. Most current police officers - both active and retired - are members of the Police Pension Scheme (PPS), which is a national unfunded contributory final salary defined benefit pension plan dating from 1987, although key principles of the scheme date back to 1921 and to subsequent legislation. Since April 2006, this scheme has been closed to new members, and new entrants to the police force are offered membership of the New Police Pension Scheme (NPPS), introduced as part of the reform process to public pension schemes that was initiated in the early 2000s (see Pensions Policy Institute, 2008). The main characteristics of the PPS and NPPS are summarised in Table 1.

Some more recent changes in police pension arrangements should be noted. First, as a result of changes to all public sector pension plans proposed by the Independent Public Sector Pensions Commission (HM Treasury 2011), the government in January raised employee contributions to both the PPS and the NPPS by, on average, 1 to $1.25 \%$ percentage points. Second, proposals stemming from both HM Treasury (2011) and Winsor (2012) to raise the normal pension age to 60 for police officers are among a number of potential changes to the pension plans that are currently under negotiation. Finally, it should be noted that the average age at which police officers enter the service has tended to rise over the last few years, not least because of the excess supply of applicants and potential recruits. This has allowed forces to recruit candidates with greater experience (including experience in police staff roles) and enhanced educational qualifications. According to the NPIA (2010), the average age of successful police applicants at national assessment was almost 27 years; long gone are the days when a new entrant to the police service had left school at age 18 , or even earlier.

3 There are recent moves away from the long process of centralisation of police finances and remuneration in England and Wales. Newly elected police commissioners will, from November 2012, be given greater discretion over how police budgets are allocated across tasks. Second, the Coalition government in power since 2010 has shown great interest in moving towards local pay variation - indeed possibly decentralised pay bargaining - although this has not so far been considered in the context of policing. See, however, Winsor (2012), Chapter 7.6 and Appendix 3, Section 6 for a further discussion of mechanisms for varying local police pay. 


\subsection{Retirement}

As shown in Table 1, normal retirement for police officers - at least for those entering the police service before 2006 - can take place after 30 years service or at age 50, with a retirement pension of up to two thirds of final salary. Although these terms are generally regarded as among the most generous on offer in public sector pension plans, especially in terms of normal retirement date, ${ }^{4}$ police forces have also been characterised by high levels of early retirement on grounds of ill-health, especially in the late 1990s when medical retirements were averaging almost half of all retirement across police forces (HM Treasury, 2000). ${ }^{5}$ Ill-health retirement rates across forces varied from less than $20 \%$ of all retirements to over $75 \%$ in the same period; the high rates being seen as arising from a combination of generous enhancement provisions (ibid, Tables 1 and 2) and weak enforcement and monitoring of medical claims by individual police forces (Poole, 1997). Ill-health retirement rates have fallen since that time, partly due to tighter monitoring and to an increased willingness of forces to place officers on 'restricted duties'.6

There are two incentives for police officers to retire on grounds of ill-health, subject of course to the loss of welfare associated with the ill-health itself. First, officers can receive a pension before their normal date of retirement (30 years' service or the earliest pension age); second, because the ill-health pension is normally enhanced by notional additional years of service.

The conditions that determine ill-health retirement for officers are underpinned by police regulations. An individual may be required to retire on medical grounds if he or she is permanently disabled; for police officers this is defined as:

"disabled from performing the normal duties of a police officer, including operational duties, until compulsory retirement age..."

\footnotetext{
${ }^{4}$ Even allowing for the higher contribution rate levied on police officers than in other public pension plans: see Pensions Policy Institute (2008). Nor is there evidence of lower life expectancy among police officers than the general population as a justification for these findings: see Government Actuary's Department (2011).

5 By way of comparison, average medical retirement rates in the same period among firefighters were $68 \%$, among teachers, $25 \%$, and in the armed forces $6 \%$. Private sector rates (for those companies with pension plans with similar provisions) typically averaged around 10\%. See HM Treasury (2000), Table 2 and Figure 3.

6 Officers on 'restricted duties' are constrained in the operational duties that they can undertake: see Winsor (2011) pp.201ff. There is no reduction in pay from being on 'restricted duties': Winsor (2012), Chapter 5, recommended that such officers should receive a pay reduction equivalent to the 'premium' in police officer pay arising from capability of full deployability.
} 
The criterion for ill-health retirement among police officers therefore stresses the officer's inability to perform 'operational duties' - that is, limits on his or her potential full deployability such as in major public order situations and other physically and mentally stressful situations. This is a stronger criterion of 'disability' than in most public social insurance settings where 'disability' would be defined by reference to capability in any employment. In the context of police officers, this definition links back to the supposed omnicompetence associated with the 'Office of Constable'. Consequently, many police officers who were unable to fulfil specific duties obtained full ill-health retirement even though they were perfectly capable of engaging in restricted activities.

In a separate but related development, the sizeable cost of ill-health retirements under the original Police Pension Scheme have induced many police authorities to encourage the possibility of alternative employment within the police service for those with restricted, but not completely disabling, injuries. The number of officers on 'restricted duties' has therefore risen quite sharply in the past decade (albeit at different rates for different forces), although it should be noted that there is at present no reduction in basic pay for an officer who is on 'restricted duties' (see footnote 6).

In addition, as noted by Poole (1997) and others, assessment procedures for ill-health retirement differed widely across police forces. In some cases, ill-health assessments would be made on an initial recommendation from a line manager and/or evidence from the applicant's doctor coupled with an in-house medical assessment, through to a much more stringent procedure based on several external medical assessments and more detailed consideration of alternative employment in the police service. Moreover, as noted by HM Treasury (2000), the police formula for ill-health retirement pension awards provides enhancement of years of service according to a non-linear formula depending on existing numbers of years' service. There are distinct 'spikes' in awards at those years of service at which the rate of enhancement increases, such as after 10 and 13 years' service. This suggests that financial incentives, as well as medical issues, played a major part in the process. Consequently, after the mid-2000s, efforts were made to implement standardised 'best practice' medical assessment procedures across forces.

The 2006 reforms to police pensions 
As noted in Table 1, in 2006 new entrants among police officers were enrolled in the New Police Pension Scheme (NPPS). In respect of conditions of service, there was one important result of the reform: the NPPS distinguishes officers who are incapable of employment in general from those capable of regular employment elsewhere. In the 2006 scheme, the latter receive an unenhanced pension. This change makes a sizeable difference to pension payouts in many simulated cases (Winsor, 2012, pp. 281-2); however most serving police officers are still covered by the earlier pension scheme which makes no such distinction.

Other changes introduced in 2006 however impact more generally on police pensions, especially the incidence of the costs of ill-health retirement. The first was a change in the financing arrangements for pensions. Under the pre-2006 funding regime, all expenditures on police pensions, whether via normal or ill-health retirement, were transferred through the main central block grant to police authorities - the Police Main Grant - from the Home Office whilst contributions by serving police officers to the police pension plans were simply transferred back to the central government: in other words, the central government financed all pension payments.

Under the arrangements from 2006-07 onwards, each police authority established a pension account into which employee and employer contributions within that police force would be paid. This would then be used to pay the pensions of both new and existing retired police officers. Given the large stock of retired police officers relative to serving police officers, this account could be topped up by central government to remain in balance. ${ }^{7}$ Under the new proposals, this 'top-up' would be done in full for 'normal' retirements. However, for ill-health retirements, the local police authority was required to pay an upfront charge of twice the average pensionable pay for the officer concerned into the pension account, with the ongoing pension award being financed from contributions or by central government subsidy (Home Office, 2005). For a realistic example, this would imply an upfront capital charge on the new pension account of three or four times the new pension award. For a plausible discount rate, and assuming life expectancy of ill-health retirees to be somewhat less than life expectancy of normal retirees, this upfront cost could constitute around one-quarter of the total projected pension cost over the remaining

7 Home Office figures suggests that, in 2008, there were around 131,000 active members of the 1987 PPS and 12,000 active members of the 2006 NPPS. There were 104,000 retired members of the 1987 PPS as well as deferred members and survivors of members who were, or would, receive pensions. 
lifetime. ${ }^{8}$ This capital charge on the local police authority would then have to be financed either from greater efficiency in spending the central grant or by raising revenue from local property taxes to rectify the shortfall in the pension account in relation to these retirements.

In addition, Home Office (2005) set a new current target maximum level of ill-health retirements of 6.5 per 1000 officers in service for every police force. Although there were no direct financial penalties as such for failing to achieve this target, clearly forces with high levels of ill-health retirement would face a proportionate higher burden on their pension accounts that would not be fully compensated from central block grants. Moreover, each police force as a whole received a series of performance targets, of which this was one, and failure to achieve these targets could invite pressure from central government and local police authorities on senior police officers, particularly Chief Constables, who are often appointed on limited tenures, to match up or leave. Combining these changes, therefore, it can be seen that central government, in the form of the Home Office, significantly altered the incentives to local police forces in relation to ill-health retirement.

\section{Modelling Ill-health Retirement}

This section investigates variations in ill-health retirement across police forces and over time. The policy reforms described in the previous section were implemented on the presumption that persistent variations in retirement rates across police forces arose largely from inadequate human resources polices and lax assessment of disability in a sub-set of forces, which would be eliminated by such reforms. However two additional sets of factors might be (i) that officers in some forces face disproportionately stressful environments with an associated persistent higher incidence of ill-health and (ii) that in contrast, variations in ill-health retirement rates from year to year are essentially random so that any statistical effects of a reform on retirement rates are essentially spurious. We investigate both these possibilities.

\footnotetext{
8 The calculation assumes retirement on a pensionable income of $£ 40,000$ at age 50 , a pension of $£ 24,000$, a real discount rate of $4 \%$ and a life expectancy beyond retirement date of around 25 years. This would of course understate the relative burden on the pension account for those officers who entered the police service later or who died much earlier due to severe disablement.
} 


\subsection{Variables associated with ill-health retirement}

We now describe the variables used in the analysis of ill-health retirement rates across police forces over time in England and Wales. We then use simple reduced form econometric models to examine factors underlying differences in ill-health retirement rates and also the impact of the 2006 reforms on retirement rates. To set the scene, Figure 1 graphs the distribution of ill-health retirement rates across police force in England and Wales for fiscal year 2005-06, just before the various reforms to the retirement regime described in the previous section were implemented. The range of ill-health retirement rates is large in Figure 1, but this may reflect transitory circumstances across police forces, especially among smaller forces where the numerator of the ratio is relatively small.

To handle this transitory aspect, Figure 2 uses panel data on ill-health retirement rates by police force to examine which police forces have systematically higher (or lower) rates than the average for the period 2002-03 to 2005-06. Running a simple fixed effects police force-level regression to control for year-on-year variability demonstrates that there are several police forces with statistically significantly higher ill-health retirement rates than the average over that period (those with significant coefficients at 5\% or above are indicated by the darker bars in Figure 2).

Given these systematic disparities in ill-health retirement rates, and in order to examine the effects of the previously described 2006 reform, a reduced form regression model is estimated to explain the determinants of the ill-health retirement rates for 42 police forces in England and Wales over the period 2002-03 to 2009-10. ${ }^{9}$ The dependent variable is the (ill-health retirement rate per 1000 police officers) $)_{i t}$ for the ith police force at time t. This rate is assumed to depend on several broad categories of factors:

- Characteristics of police officers. Ill-health may correlate with personal characteristics such as age, gender, ethnicity and underlying health. Given that we are working on forcelevel data rather than individual data, this implies that forces with, for example, a higher proportion of older police officers might have a higher ill-health retirement rate. In this data set, evidence on force-level characteristics are limited, and we use normal retirements per 1000 officers as a proxy for age structure, since there is clearly a strong correlation between

9 We exclude the (small) police force of 'City of London' from among the 43 England and Wales forces as we have no local area control variables. 
having older police officers and the incidence of normal retirement through the pension scheme. $^{10}$

- Stress and intensity of work across police forces. The argument here is that police officers working in more stressful settings (for example, inner city areas) face higher levels of risk of disability and ill-health. Several variables are used to proxy aspects of local policing, mostly taken from CIPFA (2011) and from Office of National Statistics data. The covariates utilised are:

- Local crime rate: number of notified offences per 1000 population,

- Population density per officer. This is a good proxy for operating in urban areas, but also for police force strength in the local area,

- Local crime clear-up rate as \% of recorded offences. This would clearly be an endogenous variable in a structural analysis of policing, but may capture any residual intensity of policing.

- The local area unemployment rate, using Office of National Statistics data matched into police areas. We assume that a higher rate is associated with greater deprivation and therefore potentially more stressful policing.

- The local area wage relative to the average wage for England and Wales, obtained by mapping data from the Annual Survey of Hours and Earnings (ASHE) to police authority areas. ${ }^{11}$ Again, we hypothesise that a lower local real wage in the area, relative to national wages, is associated with greater deprivation. This variable is likely to be (negatively) collinear with local unemployment (the data appendix contains summary statistics for these variables and a correlation matrix). The effects of both variables may

\footnotetext{
${ }^{10}$ Measures of the health status of police officers would obviously be a good predictors of ill-health and therefore, presumably, ill-health retirement. However Winsor (2012) noted: "The physical fitness of police officers, and some staff, are tested as part of the recruitment and probation process but, unless they undertake certain specialist roles, never again thereafter", (ibid, p.211). Extraordinarily perhaps, no data derived from fitness or health tests on police officers therefore exist.

11 It should be noted that ASHE data are the most comprehensive sources of earnings data in England and Wales, being a $1 \%$ survey of social insurance records, but that ONS applies some caveats to the employment weightings. The matching uses local authority employment weights to aggregate the pay data into police force areas.
} 
also be confounded by any effect of local unemployment rates and earnings on the outside options available to retiring police officers. ${ }^{12}$

- Police force early retirement policy. As already described, police forces have differed widely in their monitoring of ill-health and disability claims and therefore in their levels of ill-health retirement. We simply proxy this by an area force dummy variable.

- Policy changes. These involve the policy changes introduced in 2006 and described in the previous section. We characterise them by two statistical measures:

- A post-2006 dummy (commencing 2006-07) to test whether the change in the structure and finance of the police pension plan had any effect on ill-health retirement. Note this is a simple estimate in differences and will also partially capture the downward trend in police force ill-health retirements from 2002-03 onwards, and,

- An indicator of having a 'high ill-health retirement rate' pre-2006, interacted with the post-2006 dummy. This captures the policy, described in the previous section, by which central government targeted those forces with an ill-health retirement rate of 6.5 per 1000 or more from around 2006. We use two definitions of 'high ill-health retirement rate' forces, one based on 'observables' and one based on our own method of identification:

- Definition 1: those forces which had an ill-health retirement rate in excess of 6.5 per 1000 in any financial year in the period from 2003-04 to 2005-06.

- Definition 2: those forces which have a significant above average ill-health retirement rate pre-2006-07 (i.e. those with a positive and significant fixed effect as depicted in Figure 2).

In contrast to the post-2006 dummy this variable can be treated as a quasi-differences-indifferences estimator, insofar as we interpret the coefficient as the response in ill-health retirement rates of the 'high rate' forces after the policy change, relative to other forces.

12 Given that police wage rates are set nationally, the relative wage variable also effectively captures the ratio of local wages to local police wages. The mapping of local earnings into local police earnings across police forces is illustrated graphically in Winsor (2012) Volume 2, Appendix 3, pp.686-689. However it is unlikely that the average local wage fully reflects the job opportunities available to retiring police officers. In future work, we intend to use the ASHE panel on earnings to investigate where retiring police officers find work if they choose not to retire fully. 
○ Since ill-health retirement is trended downwards for much of the period, we also experiment with a trend allowing the trend to diverge between "high" and other police forces after the policy intervention.

\subsection{Results: interpretation and sensitivity tests}

The results of this exercise are described in Table 2. It shows a weak positive association of ill-health retirement rates with age structure (only close to significance in the specification with a trend) as proxied by the rate of ordinary retirements. However, we might not anticipate strong associations in the data between personal characteristics and ill-health retirement, except perhaps with underlying measures of health status that are not available for the reasons described earlier (see footnote 10).

Local variations in 'stressfulness' of policing are a more promising avenue and indeed there is statistical evidence that variation over forces and time in these indicators are correlated with illhealth retirement rates: in particular there is a weakly significant positive association with local crime rates, a strongly significant positive association with population density and (depending on specification) a significant positive association with high unemployment or a significant negative association with low wage rates relative to the national average, all as predicted $a$ priori. There is therefore evidence that variations in ill-health retirement rates across forces are not simply the result of lax administrative procedures in relation to the monitoring of poor health and disability in some forces.

Variations in stress of policing are not, however, the whole story as demonstrated when we model the policy reforms. Table 2, columns (1) and (2) use a simple 'difference' measure of the impact of the 2006 measures which suggests an average reduction in the rate of ill-health retirement rate of just under 1 in 1000 officers. From Figure 1, this is equivalent to a reduction of around a third in the average rate; however, the necessary caveat is that there is a significant downward trend in the rate from the start of the period and this coefficient may simply be capturing this initial trend. Columns (3) and (4) indeed confirm that the data are consistent with a negative time trend of 1 in 1000 per year over this period, reflecting the particularly high rate of ill-health retirement in 2002-03. 
Of more interest, therefore, is the coefficient on the interaction term 'post-2006 with high illhealth retirement rate force'. Although Definition 1 is an easily observable measures to central authorities, it is contaminated by year-on-year variance in rates of ill-health retirement, and we prefer Definition 2 as characterising forces with persistent and statistically significant aboveaverage ill-health retirement rates in the pre-2006 period. And the results in Table 2 suggest that these forces did indeed reduce their ill-health retirement rates significantly as a result of the 2006-07 policy measures - by about two-thirds of the average rate of retirement (see Figure 2) according to columns (1) and (2) and by a faster reduction in the rate post-2006 than other forces, according to columns (3) and (4).

These policy measures may therefore have had some effect in reducing both the level and variance of the rate of ill-health retirement rates across forces, notwithstanding underlying stress factors that explaining part of the differences across forces. However, it remains a possibility, especially using Definition 1 of the 'high ill-health retirement rate forces', that there is some degree of 'regression to the mean' taking place in the dispersion of retirement rates over time. We therefore undertook placebo tests which shifted the structural break from 2006-07 to other years - if the coefficient was equally significant, it suggests that we are more likely to be observing a statistical process than a policy-driven process. To summarise the results of this sensitivity analysis, we cannot rule out that the shift among high retirement rate forces took place as early as 2004-05 - though no later than 2006-07. ${ }^{13}$ This may derive from a response to early indications of the imminent policy change (Home Office, 2004, Annex B) or simply suggest that, in our relatively short data window, we cannot separately identify policy effects from statistical processes with great precision.

Next we analyse the further factor which comes to the fore in the post-2006 period. Since forces now have to finance part of their ill-health retirement from local sources (see Section 2), the possibility arises of variance in ill-health retirement rates arising from differences in the local 'taxable capacity' of local police forces. This general argument - that components of the remuneration of public sector workers can be affected by local taxable capacity - has been discussed in a small but interesting literature in the United States; it has not, to our knowledge, been discussed in any public sector labour market context in Britain.

\footnotetext{
${ }^{13}$ Results of these and other sensitivity tests are available on request from the authors.
} 


\section{The role of local finance}

\subsection{Police finances: a brief introduction}

As described in Section 2.2, for much of the previous century there was a trend towards greater central funding of local police authorities in England and Wales. This reflected, in part, the slower historic growth of the local tax base, almost wholly derived from taxes on property. However, it also highlights a trend towards greater central control of police spending, both as a means by which central government influences the allocation of police resources and activities but also in order to limit increases in property tax rates, since central government, rightly or wrongly, has tended to believe that budgetary controls on spending at the local level are considerably laxer than those enforced by HM Treasury on central spending.

The largest bulk grant for policing for England and Wales (accounting for, on average, 35\% of police finding in 2010-11) comes from the Home Office through the Police Main (or block) grant. A further, $11 \%$ comes through specific grants for particular activities and priorities (e.g. for 'neighbourhood policing' and for counter terrorism), and around 30\% from the Department of Communities and Local Government (DLCG) and the Welsh Assembly. The remaining funds are raised locally, through a precept levied on local residential properties. ${ }^{14}$

The Home Office main grant is allocated to local police forces by a complicated mechanism known as the Police Funding Formula (PFF) (Home Office, 2012). The basic Home Office grant is not just population-weighted but adjusted by the socio-economic characteristics of the population (such as measures of employment, unemployment and receipt of welfare benefits), density of population, type of housing, the spatial density of bars serving alcohol, and so on. There are further adjustments for the costs of local police (since there are some local differences in pay rates, especially for staff other than officers). The DLCG grant uses somewhat similar weighting measures through the Standard Spending Assessment (SSA); other discretionary grants have yet further mechanisms. To complicate the position further: to avoid excessive volatility in grant allocations from year-to-year by application of the PFF or SSA, there is a

\footnotetext{
${ }^{14}$ Small additional sums are raised locally from fines and fees, from some charges for policing (e.g. for certain sports events) and, for individual police forces, from lending police officers to other forces ('mutual aid') or from revenue from the loan of specialist units (e.g. underwater recovery teams) between forces. The DLCG is responsible for financing other local government activities in England; again with Council Tax and also the 'business rate' as the main sources of local finance.
} 
'damping mechanism' which allows for annual deviations in the grant from the underlying formula. These additional criteria and the 'damping mechanism' give a degree of exogeneity to central funding to police forces since, as we shall see, the capacity of police forces to raise funds from local sources depends on somewhat similar characteristics to those determining central allocations. $^{15}$

Although most financing of police forces comes through block grant funding provided by national government, a significant component - varying from $12 \%$ to $45 \%$ of total budget across forces in 2011 - is raised from local property taxes. The dominant source of local financing of police activities is the 'precept'; levied as part of Council Tax on local residential property. This tax was introduced in 1993 replacing previous property taxes, and allocates each residential property to one of eight bands assessed in 1991 in England (2003 in Wales) depending on size of the property and other features. Newly constructed properties are assigned a band and properties with major reconstruction may be rebanded. Each local authority sets a Council tax (and police precept rate) as an annual levy on a middle-banded property (Band 'D'); a nationally fixed formula then sets the rate of tax on each band as a fixed multiple or fraction of that levy. The tax base is therefore the number of 'Band D-equivalised properties' and the revenue that can be collected by a local police force from the precept depends on the total number and composition of properties in the area times the rate of precept set by the local police authority. It is therefore apparent that the elasticity of revenues from changing the precept depends on this original banding assessment of residential property in the area, as well as any new construction.

Note also that the multiple of banding rates from lowest to highest band is much more limited than the range of property values in any given area and, second, that house price increases (or falls) do not per se increase property tax revenues since the formula relating residential property type to band has remained fixed since the inception of the Council Tax. Revenues rise when the rate of precept on properties is increased, not because house values themselves rise (other than compositional effects arising from new builds and any rebanding based on home improvements). Moreover, central government has at various times attempted to cap increases in the precept of specific police forces if these are seen to be 'excessive'.

15 For further discussion, see Universities Police Science Institute (2011). This paper remarks that the current government is committed to reforming and simplifying the grant allocation procedure but notes that: 'Such is its complexity it may even be beyond significant change' (ibid, p.3) 
Figure 3 shows how the share of financing raised from the local precept varies across local police forces in 2005-06. As we model shortly, these differences partly depend on the nature of residential property, but they also depend indirectly on the formula allocating central grants, on any 'capping' procedures, and also on the expenditure needs of individual police forces. Figure 4 shows that revenue obtained from local sources by police forces tended to increase as a share of total income, especially in the first part of the period. This increase slowed in the second party of the period, in part reflecting 'capped' precept increases as part of a general attempt to limit Council tax increases by DCLG.

\subsection{Local finance and public sector remuneration: previous evidence}

The idea that the generosity of components of public sector remuneration - whether in the form of current or deferred pay - is related to local revenue-raising capacity has received little attention in the literature in Britain, both because many key public sector groups have their pay set nationally but also because public grants to local authorities are the dominant form of finance of local authorities. There is however a small but interesting published literature in the United States on the topic, but it has not focused on retirement provisions as such.

Inman (1982) examines the willingness of local jurisdictions in the United States to finance public pensions, in a context in which taxpayers have an option of funding public pensions through current taxes or by running deficits. He contrasts a 'stayer' model, in which the decision depends on borrowing costs and other factors, and a 'mover' model in which taxpayers may exit the jurisdiction before the obligation to repay unfunded public pension deficits arise. In the latter model, however, the obvious incentive to move in the face of pension deficits may be capitalised into lower property values or into lower current wages. Inman's statistical results imply a tradeoff between pension (under)funding and lower current wages of police officers, and several other public sector groups; the implicit property value capitalisation hypothesis has been tested by Epple and Schipper (1981), Leeds (1985) and Gyourko and Tracy (1989).

Gyourko and Tracy (1991) directly test whether public sector remuneration is higher, ceteris paribus, where local taxes are higher, contrasting the incidence of local sales taxes and property taxes. The nuance of the paper is that property taxes are borne more explicitly by local residents of the jurisdiction than sales taxes; therefore, where jurisdictions rely more heavily on sales taxes, then for a given tax burden public remuneration is higher. They find that police officers in 
jurisdictions with access to non-property taxes are able to increase their current remuneration by 7-9\%. However Poterba and Rueben (1995) note that some US states have imposed limits on property tax rates. These tax limits should therefore reduce public sector remuneration in affected jurisdictions, and such a finding is confirmed by thosee authors. Neither of these papers discuss the potential endogeneity of such limits, nor the interaction of property taxes (and other local taxes) with either public pensions or employment of public sector workers (e.g. financing of early retirement). In that sense, our analysis is closer to that of Inman's in terms of the financing of public pension obligations and the employment of public sector workers, but closer in methodological approach to the work of the other cited authors.

\subsection{Local finance and ill-health retirement in police: a statistical analysis}

In this final section, we examine the determinants of the 'precept' - the property tax which provides the locally-funded component of police funding. We show that the average real value of the precept levied per property in general depends on area characteristics (notably the quality and density of housing) and on the demand for police officers' services. Our primary hypothesis is twofold: first, that the level of ill-health retirement should have no effect on the precept rate pre2006, since the costs of ill-health retirement were wholly covered from central block grant funding in that period. This turns out to be the case. Second, however, there is evidence of a positive relationship post-2006, when police forces became responsible for part-funding illhealth retirement of police officers.

Our dependent variable is the real police precept levied per property (in £) by each police authority in every year. In our reduced form specification, we assume that this variable is affected by a number of factors that broadly affect the elasticity of the supply of funds and the demand for policing. We then test for any association with the rate of ill-health retirement, parimarily in the financial year 2006-07 onwards, when local police authorities became responsible for part-funding ill-health retirement. Summary statistics for both this variable and the covariates are given in the Appendix.

The supply of funds is driven by the density and banding of properties in the police authority area. We use two variables derived from CIPFA data to capture this: the number of Band-D 
equivalent properties and the size of the population. ${ }^{16} \mathrm{We}$ predict that the coefficients on these variables will be of opposite sign and that, overall, ability to raise funds is positively related to the ratio of properties per head. We also test a proposition advanced by Glaeser and Ponzetto (2012) in the context of public pensions. Since there are several billing authorities for property taxes (which incorporates the police precept) within each police authority area (because police authorities are larger administrative units than local public authorities), it may be argued that the link between local police services and the level of precept is less transparent than it is for other public services; hence the costs of the police service are partially 'shrouded' in multiple jurisdictions.

The demand for additional funds for policing is driven by the type of indicators described earlier in the context of ill-health retirement, such as the reported crime rate, clear-up rate, and measures of local deprivation. We also include the number of officers in the local police force. This variable is, strictly speaking, endogenous to a structural model of the police precept (as is, potentially, the notified crime rate). In our reduced form approach, this variable is present to capture any differential local community preferences for hiring police officers over and above those provided for from central funding.

Table 3 describes the results from various specifications. These are fixed effect models with year dummies, with the inclusion of various combinations of covariates. In general, the level of precept per property is positively associated with the number of equivalised properties and negatively associated with the size of the population, though these results are sensitive to choice of covariates. The 'shrouding' variable - number of billing authorities - is correctly signed but not significant. In some specifications, our 'demand' variables are also significant, but the reduced form nature of the specifications limits the interpretation. Clearly there is scope for fruitful further research on a more structured model of local police funding.

In the present context, however, it is the last two variables that are of primary interest. The first is 'ill health retirements per 1000 officers'. This has no effect over the period as a whole, as indeed should be the case since, until 2006, these retirements were wholly financed from central

16 To reiterate: the number of properties utilises a normalisation, like 'equivalent income', by which higher (lower) value properties are treated as a multiple (fraction) of average band properties in calculating the base. Thus an area with a high proportion of high-banded properties will be treated as if it has many more properties per head than a poorer neighbourhood with low banded residential housing (CIPFA, 2012). 
sources. However the interaction of this variable with the post-2006 period is highly significant, irrespective of the combination of covariates. This is the period when local police authorities did become partially responsible for the funding of ill-health retirement. This result is strongly consistent with the idea that some authorities were prepared to use their capacity to raise local precept in order to finance higher rates of ill-health retirement, so offsetting in part the curbs on such policies originating from central government. ${ }^{17}$

Whilst this is an interesting result in the context of the present paper, caution must be exercised before asserting that the higher precept simply paid for the higher ill-health retirement. This is because the coefficient implies that, at the mean, the amount of money raised from the precept with each extra ill-health retirement significantly exceeded the direct costs of financing that ill-health retirement for a representative pension value. Even if we allow for fixed costs of replacement and training, the figure is probably at least double the required sum. We would therefore suggest that this is an association in the data - police authorities for which it was easier to raise precept used the extra revenue for a number of activities including, inter alia, a higher level of ill-health retirement.

\section{Conclusion}

This paper has investigated the determinants of ill-health retirement across police forces over time in England and Wales. To our knowledge, this subject has never been investigated statistically, and indeed the literature on local variation in police remuneration and employment is relatively limited elsewhere also, including the United States. Given the somewhat different institutional features of police forces in Britain from those in the United States - notably central bargaining over pay and pensions - the scope for local differentiation of remuneration is currently limited. Nevertheless local police authorities in Britain have a degree of autonomy in the fraction of police funds that is raised from local sources, in the levels and deployment of police officers and staff, and in the extent of discretionary early retirement through the route of

\footnotetext{
${ }^{17}$ The lack of significance of ill-health retirement for the whole period is effectively a placebo test that we are not observing some overall spurious association between ill-health retirement and precept per property. Among our sensitivity tests, we excluded the London Metropolitan Police from the sample, since their scale of operations is so much larger than any other police force - see the statistical appendix. This exclusion made no significant difference to the findings - a result which is available on request from the authors.
} 
ill-health. Consequently ill-health retirement rates, and the degree of local funding of police activities, have varied widely over police forces. We investigate whether these variations are connected, exploiting in particular a reform of the system of police funding of pensions in 2006, which place greater financial burdens on local forces in relation to ill-health retirement.

We show using administrative data for England and Wales that police ill-health retirements are related to reasonable proxies for the stress of local policing. We show that the 2006 reform of police pensions, which contained a number of features, reduced significantly the rate of illhealth retirement, not just across all forces, but specifically among those forces that had been targeted as having 'high' rates of ill-health retirement by the Home Office. The estimated changes in rates are statistically large (relative to average ill-health retirement rates) and robust but may be subject to the effect of 'regression to the mean' in retirement rates.

Nevertheless, variations in ill-health retirement rates across police forces remained even after the 2006 reform. We test the hypothesis that forces that wished to have higher-than-average illhealth retirement rates after this date were prepared to finance these rates by levying a higher 'precept' - the component of the Council Tax on local properties which part-finances police activities. We derive a simple reduced form model to 'explain' the determinants of local real precept per head in each police authority. We show that the level of ill-health retirement was only associated positively with the precept rate from 2006-07 onwards. This strongly fits our prior hypothesis, insofar as there should have been no relationship between precept and ill-health retirement rates pre-2006 when all retirements were centrally funded. 


\section{References}

CIPFA (2011) Police Actuals, London: Chartered Institute of Public Finance and Accountancy, www.cipfastats.net/publicprotection/policeactuals/default.asp

CIPFA (2012) Understanding the Council Tax, London: Chartered Institute of Public Finance and Accountancy, http://www.cipfa.org.uk/press/download/UCT_1213.pdf

Epple, D. and Schipper, K. (1981) 'Municipal pension funding: A theory and some evidence', Public Choice, 37, 1, 141-178.

Friedberg,L. (2012) 'Retirement ages in public sector pensions and the public sector labour force'. Presented at NBER Conference: Retirement benefits for state and local employees - designing pension plans for the twenty-first century, August 2012 Jackson Hole, WY.

Glaeser, E. and Ponzetto, G. (2012) 'Shrouded costs of government: the political economy of state and local public pensions'. Presented at NBER Conference: Retirement benefits for state and local employees - designing pension plans for the twenty-first century, August 2012 Jackson Hole, WY.

Government Actuary's Department (2011) Police Pension Scheme and New Police Pension Scheme in England and Wales, Actuarial Review as at 31 March 2008 - Valuation data and demographic assumptions, November, London.

Gyourko, J. and Tracy, J. (1989) 'Local public sector rent-seeking and its impact on local land values', Regional Science and Urban Economics, 19, 3, 493-516.

Gyourko, J. and Tracy, J (1991) 'Public sector bargaining and the local budgetary process', in R. G. Ehrenberg (ed) Research in Labor Economics, 12, 117-136: Greenwich CT: JAI Press.

HM Treasury (2000) Review of ill health retirement in the public sector: London, http://archive.treasury.gov.uk/pdf/2000/ill_health110700.pdf

HM Treasury (2011) Independent Public Sector Pensions Commission: Final Report, March: http://cdn.hm-treasury.gov.uk/hutton_final_100311.pdf

Home Office (2004) National policing plan, 2005-08: Safer, stronger communities, London.

Home Office (2005) The Police Pension Scheme - new police pensions financing arrangements: Home Office circular 54/2005: London.

Home Office (2012) Police Grant (England and Wales), 2012-13, HC 1797, London: The Stationery Office.

Inman, R.P. (1982) 'Public employee pensions and the local labor budget', Journal of Public Economics, 19, 49-71.

Leeds, M. (1985) 'Property values and pension underfunding in the public sector', Journal of Urban Economics, 18, July, 34-46.

NPIA (2010) Annual Results Report 2008-09, National Policing Improvement Agency: London.

Pensions Policy Institute (2008) An assessment of the government's reforms to public sector pensions, London. 
Poole, C.J.M. (1997) 'Retirement on grounds of ill-health: cross sectional survey in six organisations in the United Kingdom', British Medical Journal, 314, 929-932.

Poterba, J.M. and Rueben, K.S. (1995) 'The effect of property-tax limits on wages and employment in the local public sector', American Economic Review, 85, 2, Papers and Proceedings, 384-389.

Universities Police Science Institute (2011) Police funding (England and Wales) 2011-12: Police Briefing Paper No 1: (author: T. Brain) Cardiff University School of Social Sciences, Cardiff.

Winsor, T. (2011) Independent review of police officer and staff Remuneration and Conditions, Part 1 Report: Cm 8024, March, TSO: London.

Winsor, T. (2012) Independent review of police officer and staff Remuneration and Conditions, Final Report: Cm 8325, March, TSO: London. 
Table 1: Summary of Police Pension Scheme and New Police Pension Scheme

\begin{tabular}{|c|c|c|}
\hline Scheme & $\begin{array}{c}\text { Police Pension Scheme } \\
\text { (PPS) } 1987\end{array}$ & $\begin{array}{l}\text { New Police Pension } \\
\text { Scheme (NPPS) } 2006\end{array}$ \\
\hline Eligibility & Joined force up to $05-04-06$ & $\begin{array}{l}\text { Joined force from 06-04- } \\
06\end{array}$ \\
\hline $\begin{array}{l}\text { Employee contribution } \\
\text { rate }\end{array}$ & $11 \%$ of salary & $9.5 \%$ of salary \\
\hline Maximum pension & $2 / 3$ final salary & $\begin{array}{l}1 / 2 \text { final salary }+4 \times \text { lump } \\
\text { sum }\end{array}$ \\
\hline Accrual rate & $1 / 60^{\text {th }} 20$ years $+1 / 30^{\text {th }}$ after 20 & $1 / 70^{\text {th }}$ \\
\hline $\begin{array}{l}\text { Maximum service full } \\
\text { pension }\end{array}$ & 30 years & 35 years \\
\hline Earliest pension & $\begin{array}{l}48.5 \text { (as early as } 46 \text { if } \\
\text { transferred in service); } \\
\text { deferred } 60\end{array}$ & 55 ; deferred 65 \\
\hline Indexation of pension & Was to RPI (2010 on to CPI) & $\begin{array}{l}\text { Was to RPI ( } 2010 \text { on to } \\
\text { CPI) }\end{array}$ \\
\hline Survivor's pension & $50 \%$ of member's pension & $50 \%$ of member's pension \\
\hline Ill-health benefit & One level of benefit & $\begin{array}{l}\text { Two tier benefit based on } \\
\text { severity }\end{array}$ \\
\hline
\end{tabular}

Notes: RPI = retail price index $\mathrm{CPI}=$ consumer price index. Under UK provisions, pension lump sums are generally treated by the tax system more favourably than annuities (pensions) up to a ceiling, therefore commutation to lump sum payments are generally favoured; in PPS, therefore, police officers could also have part of the pension taken as a lump sum (as in other pension plans). 
Table 2: Modelling ill-health retirement rates across police forces

Dependent variable: Ill-health retirements per 1000 police officers

\begin{tabular}{|c|c|c|c|c|}
\hline Explanatory variables: & $\begin{array}{c}(1) \\
\text { Definition } 1\end{array}$ & $\begin{array}{c}(2) \\
\text { Definition } 2\end{array}$ & $\begin{array}{c}(3) \\
\text { Definition } 1\end{array}$ & $\begin{array}{c}(4) \\
\text { Definition } 2\end{array}$ \\
\hline $\begin{array}{l}\text { Employee characteristics } \\
\text { Normal retirements per } 1000 \\
\text { officers }\end{array}$ & $\begin{array}{r}0.005 \\
(0.02)\end{array}$ & $\begin{array}{l}0.005 \\
(0.02)\end{array}$ & $\begin{array}{l}0.04 \\
(0.02)\end{array}$ & $\begin{array}{l}0.04 \\
(0.02)\end{array}$ \\
\hline \multicolumn{5}{|l|}{ Stress factors } \\
\hline $\begin{array}{l}\text { Crime rate (notified offences per } \\
1000 \text { population) }\end{array}$ & $\begin{array}{l}\mathbf{0 . 0 4 *} \\
(0.02)\end{array}$ & $\begin{array}{l}\mathbf{0 . 0 4 *} \\
(0.02)\end{array}$ & $\begin{array}{c}0.01 \\
(0.02)\end{array}$ & $\begin{array}{c}0.01 \\
(0.02)\end{array}$ \\
\hline $\begin{array}{l}\text { Clear-up rate (per cent of recorded } \\
\text { offences) }\end{array}$ & $\begin{array}{l}0.03 \\
(0.04)\end{array}$ & $\begin{array}{l}0.03 \\
(0.04)\end{array}$ & $\begin{array}{l}0.04 \\
(0.04)\end{array}$ & $\begin{array}{c}0.03 \\
(0.04)\end{array}$ \\
\hline Population per officer & $\begin{array}{l}\mathbf{0 . 0 5} * * * \\
(0.01)\end{array}$ & $\begin{array}{l}\mathbf{0 . 0 5} * * * * \\
(0.01)\end{array}$ & $\begin{array}{r}\mathbf{0 . 0 2} * \\
(0.01)\end{array}$ & $\begin{array}{l}\mathbf{0 . 0 2} * \\
(0.01)\end{array}$ \\
\hline Local area unemployment rate $(\%)$ & $\begin{array}{l}0.03 \\
(0.18)\end{array}$ & $\begin{array}{l}0.07 \\
(0.18)\end{array}$ & $\begin{array}{l}\mathbf{0 . 4 1} * \\
(0.18)\end{array}$ & $\begin{array}{l}\mathbf{0 . 4 6 *} \\
(0.18)\end{array}$ \\
\hline $\begin{array}{l}\text { Local area wage relative to average } \\
\text { wage }(\%)\end{array}$ & $\begin{array}{l}-\mathbf{1 1 . 8 2} * * * \\
(2.74)\end{array}$ & $\begin{array}{l}-\mathbf{1 1 . 6 4} * * * \\
(2.74)\end{array}$ & $\begin{array}{l}-4.11 \\
(2.79)\end{array}$ & $\begin{array}{l}-3.73 \\
(2.77)\end{array}$ \\
\hline Indicator: Post-2006 & $\begin{array}{r}-\mathbf{0 . 9 1 *} \\
(0.36)\end{array}$ & $\begin{array}{r}-\mathbf{0 . 9 2} * \\
(0.36)\end{array}$ & - & - \\
\hline $\begin{array}{l}\text { Interaction of Post-2006 with } \\
\text { "high" IHR force }\end{array}$ & $\begin{array}{c}-2.00 * * \\
(0.75)\end{array}$ & $\begin{array}{c}-2.24 * * \\
(0.83)\end{array}$ & - & - \\
\hline Time trend & - & - & $\begin{array}{l}-\mathbf{1 . 0 9} * * * \\
(0.16)\end{array}$ & $\begin{array}{l}-\mathbf{1 . 1 1} * * * \\
(0.16\end{array}$ \\
\hline Time trend $\times$ post-2006 & - & - & $\begin{array}{l}\mathbf{0 . 3 5} * * * \\
(0.10)\end{array}$ & $\begin{array}{r}0.36 * * * \\
(0.10)\end{array}$ \\
\hline $\begin{array}{l}\text { Time trend } \times \text { post-2006 } \times \\
\text { "high" IHR force }\end{array}$ & - & - & $\begin{array}{c}-\mathbf{0 . 3 3 * *} \\
(0.10)\end{array}$ & $\begin{array}{l}-\mathbf{0 . 4 5 * * *} \\
(0.12)\end{array}$ \\
\hline $\begin{array}{l}\text { Force dummies } \\
\mathrm{R}^{2} \\
\text { Number of observations } \\
\mathrm{F}=(.)\end{array}$ & $\begin{array}{l}\text { Yes } \\
0.7550 \\
336 \\
F(49, \\
287)=22.13\end{array}$ & $\begin{array}{l}\text { Yes } \\
0.7563 \\
336 \\
F(49, \\
287)=22.28\end{array}$ & $\begin{array}{l}\text { Yes } \\
0.7893 \\
336 \\
\mathrm{~F}(50,286) \\
=26.18\end{array}$ & $\begin{array}{l}\text { Yes } \\
0.7930 \\
336 \\
\mathrm{~F}(50,286) \\
=26.74\end{array}$ \\
\hline
\end{tabular}

Notes: 'definitions' and variables as defined in text. *, ** and *** indicate significance at the $10 \%, 5 \%$ and $1 \%$ level from a 1 -sided test. 
Table 3: Modelling real police precept levied per property (£)

\begin{tabular}{|c|c|c|c|}
\hline Explanatory variables: & (1) & $(2)$ & (3) \\
\hline $\begin{array}{l}\text { Number of Band D-equivalent } \\
\text { properties }(000 \mathrm{~s})\end{array}$ & $\begin{array}{l}\mathbf{0 . 5 9} * * * * \\
(0.08)\end{array}$ & $\begin{array}{l}\mathbf{0 . 5 4} * * * \\
(0.08)\end{array}$ & $\begin{array}{l}0.04 \\
(0.11)\end{array}$ \\
\hline Population (000s) & $\begin{array}{l}-\mathbf{0 . 1 1} * * * \\
(0.02)\end{array}$ & $\begin{array}{l}-\mathbf{0 . 1 0} * * * \\
(0.02)\end{array}$ & $\begin{array}{c}-\mathbf{0 . 0 6} * * \\
(0.02)\end{array}$ \\
\hline $\begin{array}{l}\text { Number of billing authorities in } \\
\text { police authority area }\end{array}$ & $\begin{array}{c}0.22 \\
(1.08)\end{array}$ & $\begin{array}{l}0.09 \\
(1.12)\end{array}$ & $\begin{array}{l}0.37 \\
(1.02)\end{array}$ \\
\hline Local area unemployment rate $(\%)$ & - & $\begin{array}{l}0.30 \\
(1.54)\end{array}$ & $\begin{array}{c}0.97 \\
(1.44)\end{array}$ \\
\hline $\begin{array}{l}\text { Local area wage relative to average } \\
\text { wage }(\%)\end{array}$ & - & $\begin{array}{l}-17.71 \\
(39.88)\end{array}$ & $\begin{array}{c}5.60 \\
(36.78)\end{array}$ \\
\hline Number of officers in force & - & - & $\begin{array}{l}\mathbf{0 . 0 2} * * * \\
(0.03)\end{array}$ \\
\hline $\begin{array}{l}\text { Crime rate (notified offences per } \\
1000 \text { population) }\end{array}$ & - & $\begin{array}{c}0.04 \\
(0.09)\end{array}$ & $\begin{array}{l}\mathbf{0 . 2 6} * * \\
(0.09)\end{array}$ \\
\hline $\begin{array}{l}\text { Clear-up rate (per cent of recorded } \\
\text { offences) }\end{array}$ & - & - & $\begin{array}{l}\text { 0.34* } \\
(0.17)\end{array}$ \\
\hline $\begin{array}{l}\text { Ill health retirements per } 1000 \\
\text { officers }\end{array}$ & $\begin{array}{c}-0.16 \\
(0.37)\end{array}$ & $\begin{array}{c}-0.18 \\
(0.38)\end{array}$ & $\begin{array}{l}-0.36 \\
(0.35)\end{array}$ \\
\hline $\begin{array}{l}\text { Interaction Post-2006 } \times \text { ill health } \\
\text { retirements per } 1000 \text { officers }\end{array}$ & $\begin{array}{c}\mathbf{1 . 2 1} * \\
(0.51)\end{array}$ & $\begin{array}{c}\mathbf{1 . 2 0} * \\
(0.51)\end{array}$ & $\begin{array}{l}\mathbf{1 . 2 8} * * \\
(0.47)\end{array}$ \\
\hline Force dummies & Yes & Yes & Yes \\
\hline Year dummies & Yes & Yes & Yes \\
\hline $\begin{array}{l}\text { Adjusted } \mathrm{R}^{2} \\
\text { Number of observations } \\
\mathrm{F}=(.)\end{array}$ & $\begin{array}{l}0.8896 \\
334 \\
F(53,280) \\
=51.61\end{array}$ & $\begin{array}{l}0.8886 \\
334 \\
F(56,277) \\
=48.43\end{array}$ & $\begin{array}{l}0.9061 \\
334 \\
F(58,275) \\
=56.38\end{array}$ \\
\hline
\end{tabular}

Note: Variables as defined in text. $*, * *$ and $* * *$ indicate significance at the $10 \%, 5 \%$ and $1 \%$ level from a 1-sided test. 
Figure 1: IIl-health retirement rates by police force, England and Wales, 2005-2006.

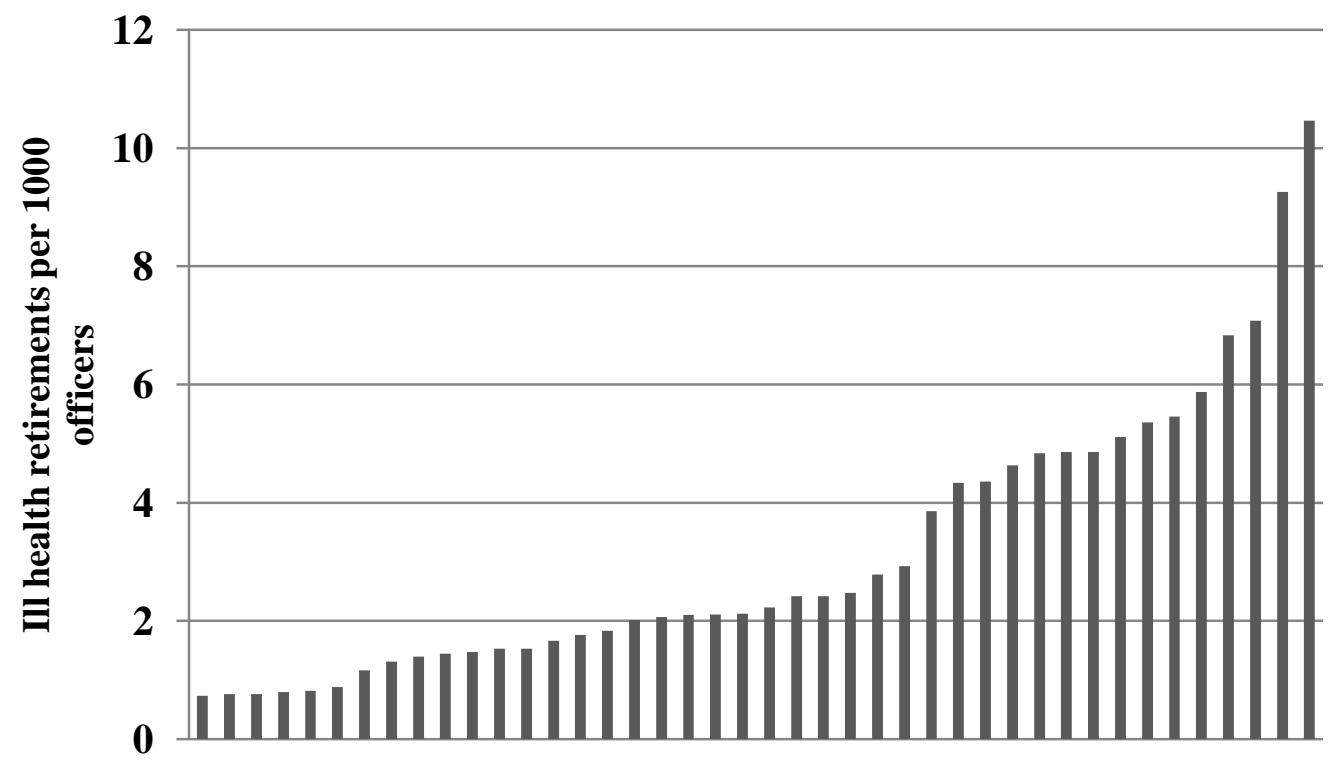

Source: Home Office returns and CIPFA Police Actuals 2005-06.

Figure 2: Differences of ill-health retirement rates (IHRRs) from average, 2002-03 to 2005-06

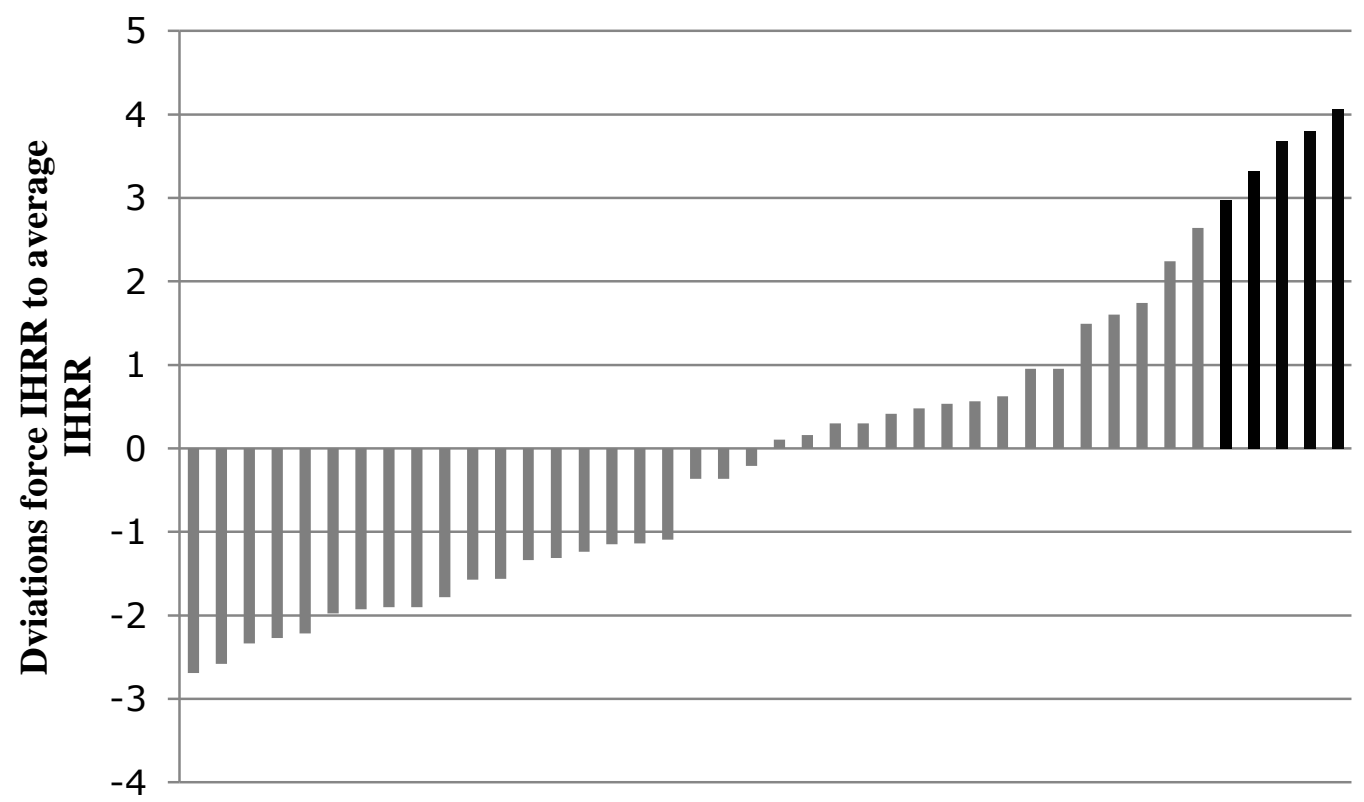

Note to Figure 2. Source: as Figure 1, various years. Estimated by regression of police area fixed effects on IHRRs for the period. Dark shaded bars are those significantly positive at $1 \%$ or $5 \%$ level. 
Figure 3: Share of funding by police force raised from local precept, 2005-06

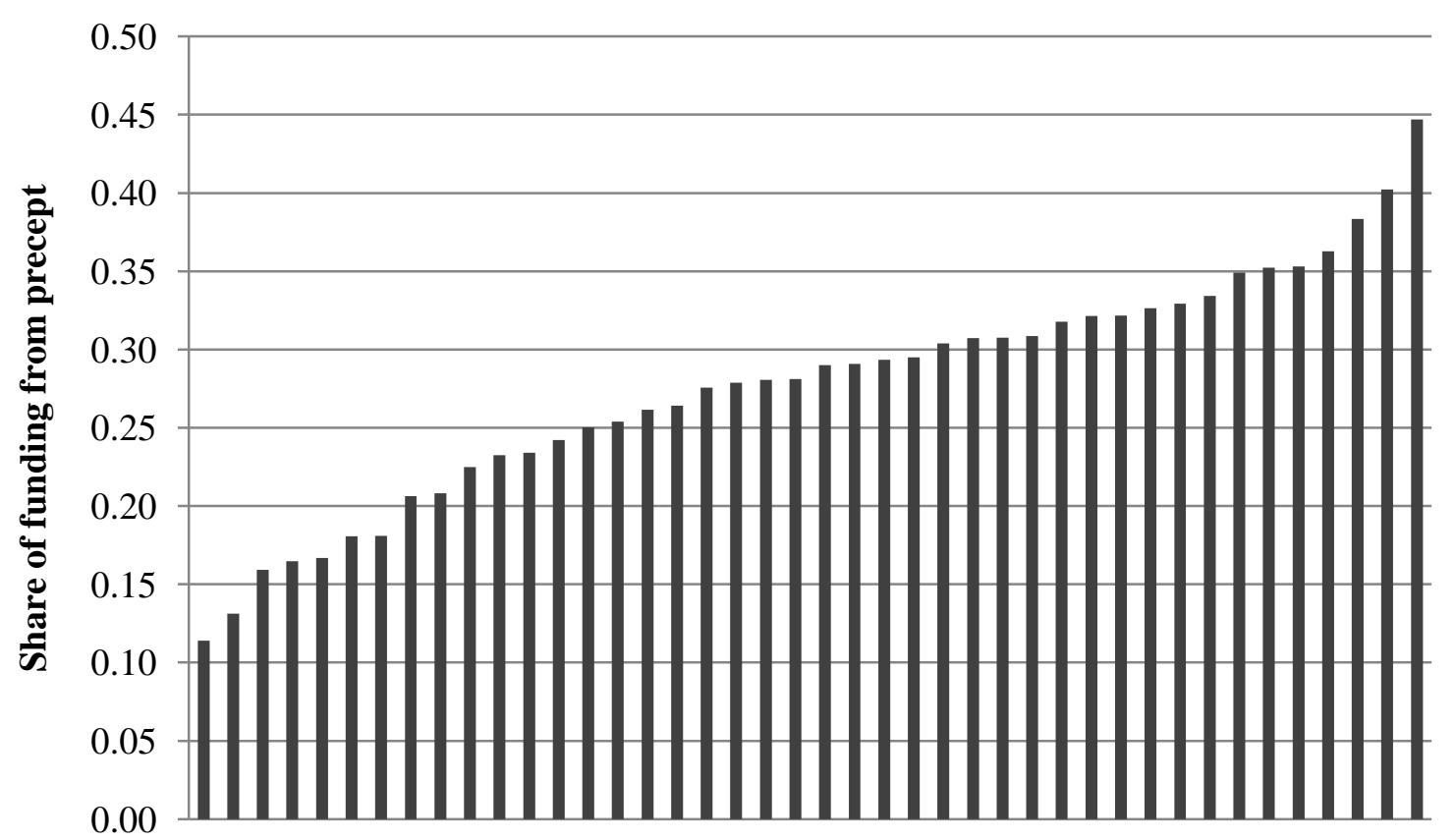

Source: CIPFA Police Actuals, 2005-06

Figure 4: Changes in the share of funding raised from local precept, 2002-03 to 2009-10

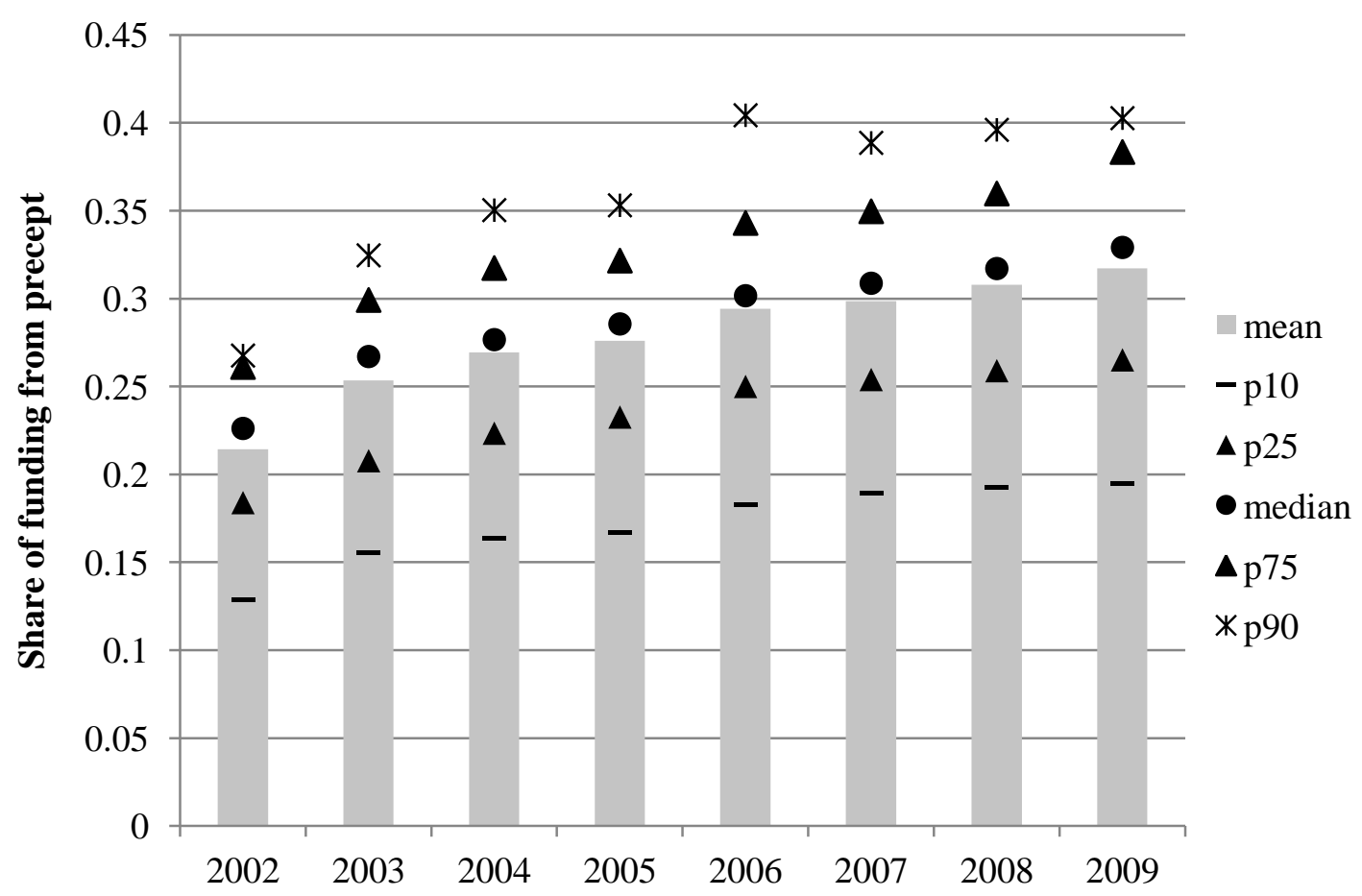

Source: CIPFA Police Actuals, various years. 
Appendix Table: Summary Statistics

\begin{tabular}{|l|c|c|c|c|c|}
\hline \multicolumn{1}{|c|}{ Variable } & $\begin{array}{c}\text { Min } \\
\text { value }\end{array}$ & Median & Mean & $\begin{array}{c}\text { Max } \\
\text { value }\end{array}$ & SD \\
\hline $\begin{array}{l}\text { Ill-health retirements per 1000 } \\
\text { police officers by force/year }\end{array}$ & 0 & 2.58 & 3.40 & 17.2 & 2.81 \\
$\begin{array}{l}\text { Normal retirements per 1000 } \\
\text { officers }\end{array}$ & 0 & 27.1 & 27.0 & 47.4 & 7.0 \\
$\begin{array}{l}\text { Crime rate (notified offences per } \\
\text { 1000 population) }\end{array}$ & 44.0 & 88.1 & 91.5 & 160.7 & 22.7 \\
$\begin{array}{l}\text { Clear-up rate for recorded crimes } \\
\text { (\%) }\end{array}$ & 14.0 & 27.0 & 28.4 & 68.0 & 6.40 \\
$\begin{array}{l}\text { Population per officer } \\
\begin{array}{l}\text { Local area unemployment rate } \\
\text { (\%) }\end{array}\end{array} 235$ & 462 & 447 & 592 & 76 \\
$\begin{array}{l}\text { Local area wage relative to } \\
\text { average wage (\%) }\end{array}$ & 0.76 & 0.91 & 0.95 & 1.38 & 0.13 \\
\hline Precept variables & 0 & 139 & 140 & 218 & 30 \\
\hline $\begin{array}{l}\text { Real police precept levied per } \\
\text { property (f) }\end{array}$ & 0.27 & 0.27 & 0.48 & 0.08 \\
$\begin{array}{l}\text { Share of funding raised by local } \\
\text { precept (\%) }\end{array}$ & 0 & 333 & 458 & 3495 & 497 \\
$\begin{array}{l}\text { Number of Band D-equivalent } \\
\text { properties (000s) }\end{array}$ & 162 & 1012 & 1355 & 11448 & 1649 \\
$\begin{array}{l}\text { Population (000s) } \\
\begin{array}{l}\text { Number of billing authorities in } \\
\text { police authority area }\end{array}\end{array}$ & 2 & 6 & 8.7 & 32 & 5.2 \\
$\begin{array}{l}\text { Number of officers in force } \\
\text { (FTEs) }\end{array}$ & 948 & 2170 & 3266 & 32988 & 4507 \\
\hline
\end{tabular}




\begin{tabular}{|c|c|c|c|c|c|c|c|c|c|c|c|c|c|c|}
\hline Corre lation matrix & $\begin{array}{l}\text { Precept } \\
\text { as } \% \\
\text { funding }\end{array}$ & $\begin{array}{l}\text { Total real } \\
\text { precept } \\
\text { raised }\end{array}$ & $\begin{array}{l}\text { Real } \\
\text { precept per } \\
\text { dwelling }\end{array}$ & Population & $\begin{array}{l}\text { Total } \\
\text { value of } \\
\text { taxbase }\end{array}$ & $\begin{array}{l}\text { Number } \\
\text { Band D } \\
\text { dwellings }\end{array}$ & $\begin{array}{l}\text { No of } \\
\text { officers }\end{array}$ & $\begin{array}{l}\text { Rate of } \\
\text { IHR }\end{array}$ & $\begin{array}{l}\text { Crime } \\
\text { rate }\end{array}$ & $\begin{array}{l}\text { Clear up } \\
\text { rate }\end{array}$ & $\begin{array}{l}\text { Population } \\
\text { per officer }\end{array}$ & $\begin{array}{l}\text { Rate of } \\
\text { OHR }\end{array}$ & $\begin{array}{l}\text { Unemploym } \\
\text { ent rate }\end{array}$ & $\begin{array}{l}\text { Local wage: } \\
\text { national wage }\end{array}$ \\
\hline Precept as \% funding & 1 & & & & & & & & & & & & & \\
\hline Total real precept raised & -0.0639 & 1 & & & & & & & & & & & & \\
\hline Real precept per dwelling & 0.7751 & 0.2063 & 1 & & & & & & & & & & & \\
\hline Population & -0.3144 & 0.8898 & -0.0872 & 1 & & & & & & & & & & \\
\hline Total value of taxbase & -0.2589 & 0.9012 & -0.0719 & 0.9944 & 1 & & & & & & & & & \\
\hline Number Band D dwellings & -0.0681 & 0.7236 & -0.0709 & 0.7739 & 0.8112 & 1 & & & & & & & & \\
\hline No of officers & -0.3679 & 0.8906 & -0.0872 & 0.9905 & 0.977 & 0.7184 & 1 & & & & & & & \\
\hline Rate of IHR & -0.0655 & -0.1809 & -0.11 & -0.1543 & -0.1722 & -0.1746 & -0.162 & 1 & & & & & & \\
\hline Crime rate & -0.6562 & 0.1891 & -0.3656 & 0.3434 & 0.2969 & 0.0589 & 0.3757 & 0.1199 & 1 & & & & & \\
\hline Clear up rate & 0.1867 & -0.1879 & 0.2206 & -0.2742 & -0.2739 & -0.1646 & -0.2479 & 0.0749 & -0.4848 & 1 & & & & \\
\hline Population per officer & 0.6803 & -0.336 & 0.1931 & -0.4592 & -0.4051 & -0.1149 & -0.5483 & 0.0934 & -0.5159 & -0.0695 & 1 & & & \\
\hline Rate of OHR & 0.1073 & -0.0601 & 0.1287 & -0.0925 & -0.0967 & -0.113 & -0.0911 & -0.0127 & -0.1128 & 0.0443 & 0.0574 & 1 & & \\
\hline Unemployment rate & -0.3783 & 0.1768 & 0.0172 & 0.2401 & 0.2013 & -0.0385 & 0.3015 & -0.1151 & 0.1376 & 0.0529 & -0.5829 & 0.1011 & 1 & \\
\hline Local wage: national wage & 0.2562 & 0.4323 & 0.0448 & 0.409 & 0.4679 & 0.461 & 0.3454 & -0.1822 & -0.0965 & -0.3103 & 0.2746 & -0.1381 & -0.2633 & 1 \\
\hline
\end{tabular}

